\title{
Survival of patients with non-small cell lung cancer and brain metastases
}

Link to publication record in Manchester Research Explorer

\section{Citation for published version (APA):}

Mulvenna, P., Barton, R., Wilson, P., Faivre-Finn, C., Nankivell, M., Stephens, R., Langley, R., Moore, B., \& Ardron, D. (2011). Survival of patients with non-small cell lung cancer and brain metastases. Clinical Oncology, 23, 375.

\section{Published in:}

Clinical Oncology

\section{Citing this paper}

Please note that where the full-text provided on Manchester Research Explorer is the Author Accepted Manuscript or Proof version this may differ from the final Published version. If citing, it is advised that you check and use the publisher's definitive version.

\section{General rights}

Copyright and moral rights for the publications made accessible in the Research Explorer are retained by the authors and/or other copyright owners and it is a condition of accessing publications that users recognise and abide by the legal requirements associated with these rights.

\section{Takedown policy}

If you believe that this document breaches copyright please refer to the University of Manchester's Takedown Procedures [http://man.ac.uk/04Y6Bo] or contact uml.scholarlycommunications@manchester.ac.uk providing relevant details, so we can investigate your claim.

\section{OPEN ACCESS}


short term clinical recurrence rates similar to those of traditional thyroid hormonal withdrawal. J Nucl Med 2008;49(5): 764-770.

[3] Elisei R, Schlumberger M, Driedger A, et al. Follow-up of lowrisk differentiated thyroid cancer patients who underwent radioiodine ablation of postsurgical thyroid remnants after either recombinant human thyrotropin or thyroid hormone withdrawal. J Clin Endocrinol Metab 2009;94(11):4171-4179.

[4] Sipos JA, Mazzaferri EL. Thyroid cancer epidemiology and prognostic variables. Clin Oncol 2010;22(6):395-404.

(c) 2011 The Royal College of Radiologists. Published by Elsevier Ltd. All rights reserved.

doi:10.1016/j.clon.2011.01.506

\section{Survival of Patients with Non-small Cell Lung Cancer and Brain Metastases}

Sir - The members of the Quality of Life after Treatment for Brain Metastases Trial Management Group (QUARTZ TMG) note the recent articles in Clinical Oncology, 2010, Volume 22 referring to the above. The first is a letter from colleagues in the UK describing their experience of survival for the above patient group [1]. The second is a retrospective audit from colleagues in India assessing the applicability of the Radiation Therapy Oncology Group (RTOG) recursive partitioning analysis prognostic classes for brain metastases in this context [2]. We applaud the continued interest in the optimal treatment of patients with non-small cell lung cancer and brain metastases, but must highlight a number of issues within these publications that cause us concern.

The letter from Bradley et al. [1] concerns a retrospective analysis of a small number of highly selected patients, with only the better performance status patients (World Health Organization 0 and 1; Karnofsky performance score [KPS] 100-70) receiving whole brain radiotherapy (WBRT). Although performance status is a well-known and important prognostic factor, it has never been shown to be a predictor for a response or lack of one to a specific treatment - in this case WBRT [3]. We thus question the use of this sole measure to determine treatment. Any measured difference in survival within this non-randomised highly selected group cannot solely be attributed to the decision to provide or not to provide WBRT, particularly in view of the heterogeneous list of other treatments this patient group received.

In the publication from Mumbai [2], the main conclusion was that $20 \mathrm{~Gy}$ in five fractions is as effective as longer fractionated courses. This fact has already been shown by the multiple RTOG dose-finding trials in the 1970s and 1980s [4,5], the Royal College of Radiologists' publication from 1996 [6] and the Cochrane review of 2006 [7]. However, as the Cochrane review points out, there has never been a full randomised controlled trial of supportive care plus or minus WBRT and this information is of utmost importance, particularly in the non-small cell lung cancer group. Within the Mumbai series, poor survival times were again seen: median overall survival was 4.0 months (range $0.5-30.0$ months) and emphasised that the central question being addressed by QUARTZ remains as valid as ever.

Similarly, the addition of systemic therapy to WBRT, which occurred in both publications, cannot be claimed to improve survival as those patients receiving this treatment fall within a self-selecting population, with only the fittest patients (and thus those with the better prognoses) receiving treatment. Of the various prognostic factors explored in the publication from Mumbai, recursive partitioning analysis class (II versus III, $P$ value $=0.023$ ), KPS ( $<70$ versus $\geq 70, P$ value $=0.039$ ) and the use of systemic therapy emerged as significant on univariate analysis. The use of systemic therapy in these patients again reflects their performance status-it cannot be concluded that the use of systemic therapy improved survival from the data presented.

Systemic therapies may have a role to play, but that role must be explored and elucidated in randomised clinical trials. QUARTZ continues to play an important role in establishing the standard of care against which these new modalities should be tested.

A recent release of preliminary data from the first 151 QUARTZ patients (manuscript in preparation) suggests that not using WBRT does not result in obviously shortened survival or decreased quality of life. These data show a 6 month survival rate of $<10 \%$, suggesting that no particular group of patients greatly benefits from WBRT. The wide range of baseline characteristics observed in the QUARTZ data (50\% of patients entered were of KPS $>70 ; 50 \%<$ KPS 70) suggests that there remains widespread uncertainty over how to treat all patients, regardless of performance status. WBRT may be effective in some patients, but at present there is little evidence to allow the identification of those patients. This interim release has been helpful to reassure clinicians and patients partaking in QUARTZ that no harm is seen in either arm from the point of view of the length of survival. To fully answer the questions that pertain to potential benefits from WBRT re survival and patientassessed quality adjusted life years (the primary end point of QUARTZ), we must await completion of this trial to attain the statistical power required.

The view of the QUARTZ TMG is that both publications $[1,2]$ used cohorts of patients who had received WBRT to support the use of WBRT, but using such data can never produce the justification for this assumption. It may indeed be that all patients benefit from WBRT, but equally the data presented (because of the poor survival) could indicate that it is actually detrimental to all patients. The likelihood is that some subgroups of patients benefit and some do not, but only by performing large randomised trials, and comparing those who received WBRT with a comparable 
group who did not, can we tease out these differences. Clinical practice must be evidence based, not anecdotal. All patients deserve the best available treatment, and the best way of determining that is within clinical trials. Early QUARTZ data suggest there is considerable uncertainty as to how these patients should be treated, and further investigation is essential. Patients with non-small cell lung cancer and brain metastases who may have received chemotherapy or targeted agents up front remain eligible for QUARTZ. As such, we believe all patients, regardless of performance status, should be considered for QUARTZ, and that the current standard of care for these patients should be inclusion in the trial.

P. Mulvenna*, R. Barton†, P. Wilson $\downarrow$, C. Faivre-Finn§, M. Nankivell||, R. Stephens $\Upsilon^{1}$, R. Langley $\|$, B. Moore $\uparrow$, D. Ardron $\|^{2}$ *Northern Centre for Cancer Care, Newcastle upon Tyne NE7 7DN, UK $\nmid$ Princess Royal Hospital Hull, UK $\ddagger$ University Hospitals Bristol, UK $\S$ The Christie NHS Foundation Trust, Manchester, UK ||Medical Research Council Clinical Trials Unit, London, UK qNational Institute for Social Care and Health Research Clinical Research Centre, Cardiff, UK

${ }^{1} \mathrm{Mr}$ Stephens has retired from his post of senior statistician at the MRC and thus has no affiliations apart from remaining an active and valued member of the QUARTZ Trial Management Group. ${ }^{2} \mathrm{Mr}$ Ardron is the consumer representative on the QUARTZ Trial Management Group.

\section{References}

[1] Bradley KL, Lwin MT, Lawrence VM. Survival of patients with non-small cell lung cancer and brain metastases and QUARTZ in practice. Clin Oncol 2010;22:892.

[2] Agarwal JP, Wadasadawala T, Munshi A, et al. Validation of recursive partitioning analysis classification in patients with brain metastases from non-small cell lung cancer treated with short course accelerated radiotherapy. Clin Oncol 2010;22: 837-843.

[3] Nieder C, Mehta MP. Prognostic indices for brain metastases usefulness and challenges. Radiat Oncol 2009;4:10.

[4] Borgelt G, Gelber R, Kramer S, et al. The palliation of brain metastases: final results of the first two studies by the Radiation Therapy Oncology Group. Int J Radiat Oncol Biol Phys 1980;6:1-9.

[5] Borgelt B, Gelber R, Larson M, Hendrickson F, Griffin T, Roth R. Ultra-rapid high dose irradiation schedules for the palliation of brain metastases: final results of the first two studies by the Radiation Therapy Oncology Group. Int J Radiat Oncol Biol Phys 1981;7:1633-1638.

[6] Priestman TJ, Dunn J, Brada M, Rampling R, Baker PG. Final results of the Royal College of Radiologists' trial comparing two different radiotherapy schedules in the treatment of cerebral metastases. Clin Oncol 1996;8:308-315.

[7] Tsao MN, Lloyd N, Wong R, Chow E, Rakovitch E, Laperriere N. Whole brain radiotherapy for the treatment of multiple brain metastases. Cochrane Database of Systematic Reviews 2006; Issue 3. Art. No.: CD003869, doi:10.1002/14651858. CD003869.pub2.

\section{Magnetic Resonance Image-based Dose Volume Parameters and Clinical Outcome with High Dose Rate Brachytherapy in Cervical Cancers - A Validation of GYN GEC-ESTRO Brachytherapy Recommendations}

Sir - The GYN GEC-ESTRO Brachytherapy Working Group has recommended contouring guidelines, concepts and terms in three-dimensional magnetic resonance imagebased treatment planning in cervical cancer brachytherapy $[1,2]$, with reports confirming the safety, feasibility, definite advantages, clinical outcome and late toxicities (limited series) [3,4]. We evaluated 24 patients treated with high dose rate brachytherapy who underwent at least one magnetic resonance scan for planning between May 2006 and December 2007 as a part of validation and implementation of the guidelines in a developing country setting. In our series, the mean High Risk Clinical Target Volume (HR-CTV) was $45.2 \pm 15.8 \mathrm{~cm}^{3}$, which is higher than the reported series, suggesting larger residual tumour volumes at brachytherapy and would require additional interstitial needles/tubes together with tandem ring/ovoids for better target coverage. The mean point A dose was $73.4 \pm 4.5 \mathrm{~Gy} 10$ (median: 74.3), whereas the mean $D_{90}$ doses were $70.9 \pm 10.6$ Gy10 (median 68 ). The mean ICRU rectal and bladder points were $63.5 \pm 8.1 \mathrm{~Gy} 3$ and $80.4 \pm 34.4 \mathrm{~Gy} 3$, respectively. The $D_{0.1} \mathrm{~cm}^{3}$ and $D_{2 \mathrm{~cm}^{3}}$ for the rectum were $66.0 \pm 9.9 \mathrm{~Gy} 3$ (median 64.5) and $57.8 \pm 7.7 \mathrm{~Gy} 3$ (median 58.8), for the bladder were $139.1 \pm 54.7 \mathrm{~Gy} 3$ (median 131.9) and $93.4 \pm 24.6 \mathrm{~Gy} 3$ (median 91) and the sigmoid were 109.4 $\pm 45.2 \mathrm{Gy3}$ (median $91 \mathrm{~Gy}$ ) and $74.6 \pm 19.6 \mathrm{~Gy} 3$ (median 69.6).

With a median follow-up of 24 months (mean 26 months; range 16-42 months), three patients had local failures; one had positron emission tomography-computed tomography- and biopsy-proven right external iliac nodal failure and one patient had a cytology-proven left supraclavicular nodal failure. Of three local failures, two patients had persistent and progressive local disease and received the following doses at point A: 70 Gy10 and $D_{90} 65$ Gy10 (FIGO IIIB); 79 Gy10 and $D_{90} 67$ Gy10 (FIGO stage IIB), respectively, whereas the third patient with FIGO stage IIB developed local recurrence at the cervix 10 months after treatment. The mean survival was 30 months and actuarial disease-free survival was $71 \%$ at 2 years. So far, only one patient has grade 3 radiation proctosigmoiditis at 12 months after treatment with rectum 2 and $0.1 \mathrm{~cm}^{3}$ doses of 